\title{
The promise of social franchising as a model to achieve social goals
}

\author{
Thierry Volery \& Valerie Hackl \\ University of St. Gallen \\ Email: thierry.volery@unisg.ch
}

Social entrepreneurship implies a blurring of sector boundaries. In addition to innovative notfor-profit ventures, social entrepreneurship can include social purpose business ventures, such as for-profit community development banks, and hybrid organizations mixing not-for-profit and for-profit elements (Dees, 1998). Despite this broad playing field, it generally agreed that the central driver for social entrepreneurship is the social problem being addressed, and the particular organizational form a social enterprise takes should be a decision based on which format most effectively mobilize the resources needed to address that problem. (Austin et., 2006). Social entrepreneurs, therefore, look for the most effective methods of serving their social missions.

One of the main challenges for social entrepreneurs has been to scale up their venture. Although these entrepreneurs may have a clear understanding of the needs in a given community and be able to raise the necessary capital to start social venture, they are frequently unable to develop or scale up the service delivery, marketing, and accountability challenges that all small businesses face (Zahra et al., 2008). Consequently, the impact of social entrepreneurs are usually limited to a specific region and there is a growing interest in business models which could help extending initiatives to further locations and let more people benefit from the products and services.

Franchising can represent an effective approach to mastering the complexities to replicate a proven concept. It not only promises to help address the question of how to provide innovative entrepreneurs with the structure and support necessary to convert their interest in social enterprises into sustainable businesses, but it also provides a roadmap for implementing these ventures. Social franchising is an adaptation of commercial franchising in which the developer of a successful social concept (franchisor) enables others (franchisees) to replicate the model using a proven system and a brand name to achieve a social benefit. Social franchising can be defined as a system of contractual relationships, which uses the structure of a commercial franchise to achieve social goals (Tracey \& Jarvis, 2007). As such, it is a new institutional arrangement in the field of social entrepreneurship and it represents a promising leverage tool to achieve social goals.

The goal of this chapter is to outline the potential of social franchising as an organizational form to grow social ventures. Specifically, we examine the relevance of two main theories agency theory and social capital theory - for social franchising. This leads to a description of the data collection and analysis procedure. Following an account of a multiple case study, we then consider the structure and coordination features of social franchising and distinguish them from commercial franchises.

\section{Theoretical framework}

Commercial franchising is essentially a long-term contractual relationship, where one party, the franchisor, provides a business concept to one or more other parties, the franchisees, who 
in return agree to pay a franchise fee. The franchisor is generally obliged to continuously refine the concept, provide training to the franchisees and arrange a consistent marketing appearance. The franchisees usually are responsible to deliver performance reports, market information to the franchisor, and handle all customer belongings (Skaupy, 1995).

Social franchising however differs greatly from traditional franchising structures in several ways. The first difference pertains to the underlying mission (social vs. profit), which in turn may lead to different types of franchise concepts (social vs. business program) and different types of target groups (beneficiaries vs. customers). Second, the franchise units involved in social franchising vary from their commercial counterparts (e.g. social enterprises vs. individual business people) (Ahlert et al., 2008). Third, the actors engaged in social franchising usually adhere to different values: social entrepreneurs are more concerned with caring and helping than with merely "making money". (Thompson, 2002)

Three main approaches have been used to explain business format franchising: resource scarcity, social capital theory and agency theory. While the agency and social capital theories have widely applied in the field of franchising, the potential of resource scarcity remains doubtful (Combs et al., 2004). Accordingly, we focus on the agency and social capital perspectives.

\subsection{Agency theory}

Agency theory is concerned with contractual relationships between a principal (the franchisor) and an agent (the franchisee) where the former delegates a set of tasks to the latter (Ross, 1973). Two assumptions are inherent to the theory and drive complexity in agency relationships (Spremann, 1987). First, external effects arise as the agent's behaviour affects not only its own but also the principal's success. This fact is particularly problematic when it comes to the second assumption of information asymmetries between the principal and his agent. Information asymmetries are caused by a loss of control over intentions and behaviours of the agent, because the principal cannot monitor all actions of the agent. Therefore, agency theory considers economic actors as self-interested and most likely to engage in opportunistic behaviour.

This brew of factors demands coordination mechanisms that enable the principal to exercise a certain level of control over his agent. While agency theory considers contracts as the main coordination mechanism to steer actions in a favourable way, it is impossible to specify all future circumstances. The inability to establish complete contracts leads to agency threats called adverse selection, moral hazard and hold up (Carney \& Gedajlovic, 1991). The former refers to the risk of selecting actors not well suited to achieving desired outcomes. Moral hazard relates to potential risks when contracting with individuals who withhold effort (shirking) or misappropriate firm resources (free riding). Hold up describes risks stemming from unequal bargaining power between cooperation partners due to specific investments.

In the context of franchising, agency theory suggests, "there is likely to be greater goal divergence between franchisors and hired managers than between franchisors and franchisees" (Garg \& Rasheed, 2003: 331). The basic premise of this argument focuses on the variability of the franchisee's compensation with unit performance. Consequently, a franchisee has a dual incentive to maximise sales revenue through effective management and promotion of the franchise concept, while minimizing variable costs. Under a franchising contract, franchisees bear the undiversifiable residual risk tied to their particular units, and 
therefore, "the costs and benefits of franchisees' actions that affect the value of their individual units are capitalized onto their own shoulders". The moral hazard of suboptimal efforts is thus less likely by franchisees than it is by hired managers (Shane 1996).

Being residual claimants to net proceeds, franchisees have an incentive not to shirk. As a result, the need for monitoring is reduced, as a franchisee's effort is self-enforced. However, the franchisor still maintains some decision rights such as menu selection, building design, and site location. The franchisor has authority to monitor the franchisee for product quality and franchisee shirking if detected, could result in the termination of the contract.

\subsection{Social capital theory}

Social capital theory is characterized by an interdisciplinary heterogeneity and it has only recently found its way into economics (Adler \& Kwon, 2002). Despite its relatively young age, it has been widely adapted in various disciplines, such as sociology, political science, and economics. As suggested by Nahapiet \& Goshal (1998: 243), social capital is "the sum of the actual and potential resources embedded within, available through, and derived from the network of relationships possessed by an individual or social unit”.

Social capital can be tackled either from a macro level or from a micro level perspective (Lin, 2001). On the macro level, social capital is recognized as a collective good or asset produced by a group of people. This view is called internal perspective, because the relations within social systems are the primary focus of analysis. Social capital can also be tackled from a micro level perspective when the emphasis is on individuals rather than groups. This view is called external perspective as it deals with individuals as part of a web of relations.

While these two perspectives help in classifying social capital, we would like to draw the attention on two dimensions clustering attributes of social capital: the structural and the relational dimension. Both of them are highly interrelated and provide a theoretical basis for the theoretical framework of social franchising.

The structural dimension refers to patterns of relations within a social system or in other words, "who you reach and how you reach them" (Burt, 1992). Important aspects of the structural dimension are the access to resources of other members within the social system and the structure of the social network. Some scholars like Granovetter (1973) and Burt (1992) point to the value of structural holes in networks enabling a bridging function to access resources beyond those available in their own social surroundings. Others such as Coleman (1990) emphasize the function of closed networks with a high number of ties between the members of a network. Here the bonding function enables the observance of norms and the power of sanction in case of violation.

The relational dimension refers to the substance and quality of social relations. The focus lies on the resources embedded in and activated through relations. These resources include trust, norms and identity. Trust is an actor's expectation of the other party's competence and goodwill and is both a requirement and a result of social relationships (Blomqvist, 1997). A norm can be defined as a rights allocation under which control over a target action is held by actors other than the one who might take the action and Coleman (1990) stresses the importance of closed networks for the emergence of norms. One norm of special attention is the concept of reciprocity, where one individual is obliged to return someone else's previous favour (Schechler, 2002). Identification can be described as the perception of oneness with or 
belongingness to some human aggregate (Ashforth \& Mael, 1989) and plays an important role when it comes to collective networks.

\subsection{Towards an integrated framework}

An integrated theoretical framework on social franchising can be built on the agency theory as traditional franchising approach and on social capital theory as a complementary bundle of constructs. In this section, we suggest to draw the sound, albeit limited contribution of agency theory as starting point, and to expand it gradually by adding concepts from social capital theory. This approach is based on three premises. First, the traditional view of economic actors as homo economicus is inadequate for social franchising. We propose the concept of homo reciprocans to characterise the parties involved in social franchising. Second, contractual arrangements must be completed by social concepts such as trust, commitment and identification. Third, social franchises can be described as networks where the social dimensions play a central role.

The concept of "homo economicus" has been traditionally employed in economics to describe economic actors characterized by self-interest, rational behaviour, and profit maximization. This view results in a short-run perspective pervasive in agency theory, which forces the rational individual to prioritize actions yielding in direct positive returns (Franz, 2004). This narrow view does not necessarily hold true, especially when dealing with socially engaged individuals where cooperative behaviour is the norm. Therefore, we suggest to depart from the homo economicus and to adopt the concept of reciprocity from the social capital theory. This implies that individuals do not only consider short-term objectives, but also rather adopt a longer-term view where rights, obligations and returns will balance out in a more or less distant future. By integrating the concept of reciprocity into homo economicus, cooperative behaviour becomes reasonable also from a rational point of view (Adler et al., 2002). This new concept is called homo reciprocans and represents the foundation of our framework.

When scholars write about contracts regulating agency relationships they typically refer to explicit contractual documents (Ripperger, 1998). However, legal contracts are incomplete and their value in holding off undesired behaviour is limited (Macaulay, 1963). Regardless of the duration of an exchange, it is practically impossible to specify contractually all dimensions of the exchange. Further, managers are constrained in their capacity to anticipate and contractually resolve all potential future contingencies. As a result, contracts are limited in their effectiveness in maintaining the continuity of the relationship.

We therefore point to the importance of social governance systems as a complementary coordination tool. Morgan \& Hunt (1994) have argued that trust, commitment and identification are central to any relationship. In the case of social franchising, these encourage franchisors and franchisees to work together to preserve relationship investments and to minimize opportunistic behaviour by resisting attractive short-term alternatives in favour of the expected long-term benefits of staying together. According to Morgan \& Hunt (1994: 22), "when both commitment and trust are present, they produce outcomes that promote efficiency, productivity and effectiveness." In short, commitment and trust lead to cooperative behaviours that are conducive to relationship, including franchise relationship, success.

In order to generate a holistic view on social franchising it is also necessary to take a closer look at the underlying structure of the franchise. For this, we suggest using the structural perspective of social capital theory. This view considers the social franchise system as a 
network consisting of franchisees at the network intersections as do strategic network scholars looking at traditional franchise networks (Sydow, 1998). Most likely the system follows an egocentric structure with the franchisor is positioned in the centre. Various aspects of the network dimensions can be considered to describe the franchise. This includes the density of the network as indicator for the quality of internal relations, as well as the strategic positioning of franchise actors indicating key actors within the system. Similarly, the concept of "structural holes" as proposed by Granovetter (1983) and Burt (1992) reflect the effect of the relationship between the franchise partners in gaining access to local networks and resources of the franchisee (i.e. bridging function).

\section{Method}

A case study approach was adopted to collect data. A case study is considered an appropriate strategy for answering research questions that ask 'how' and 'why' and that do not require control over events (Robson 1993) because such questions deal with operational links that need to be traced over time, rather than mere frequencies or incidence. By using a case study approach, the reasons why particular decisions were made, how they were implemented and results obtained can be identified and understood.

This research method is ideal to investigate the social franchise phenomenon. On the one hand, scant research has been conducted in this field to date. On the other hand, the specific questions about the steering mechanisms and structural features of the franchise system call for a method that provides a rich and holistic analysis, which is extremely useful in revealing complexity and dynamism. Moreover, a quantitative evaluation can hardly be imagined if we consider the small number of existing social franchises.

The exploratory case study seeks to find out what is really happening, to scale new heights, to ask new questions and to assess phenomena in a new light (Robson 1993). Consequently, we focus on current events and concerns and seek to answer questions of how and why. Yin (2003) favours exploratory case studies only when available research or the existing knowledge base is poor, as in the field of social franchising.

This present study was designed as a multiple-case study comprising three purposely-selected social franchises (Dialogue in the Dark, Science-Lab and VisionSpring). The data were collected from two different sources - documents and interviews - to provide triangulation. Documents included franchise agreements, online materials, newspaper clippings, and magazine articles. In addition, we conducted a series of semi-structured interviews with the franchisor and at least one franchisee in each franchise system. We also interviewed employees in key positions if this was desirable. A total of 11 interviews were conducted.

We adopted the following techniques suggested by Eisenhardt (1989) to analyse the data: (1) analysing within case data, (2) searching for cross-case patterns, (3) enfolding literature and (4) reaching closure. The case analysis is based on classic content analysis but does not require data to be quantified. To begin with, a system of categories was developed based on a theoretical treatment of the data (theoretically deductive). In a second phase, this category system was complemented with results from the field under investigation (empirically inductive).

\section{Description of the three cases}




\subsection{Dialogue in the Dark}

Dialogue in the Dark was established by Andreas Heinecke in Hamburg, Germany, in 1988. The organisation aims to "promote social creativity and new opportunities to raise social awareness about issues of old age, troubled youth, the poor, the unemployed, and the conditions of differently-abled people." The social venture organises exhibitions in which blind people lead sighted people through darkened rooms, thus providing them with an idea of their own dark world. Visitors, who are merely armed with sticks, are led by blind people in small groups through varying everyday situations such as a park or streets. Besides guiding groups of visitors, blind people, partially sighted people and people with other disabilities largely manage the exhibition locations themselves.

The programme thus pursues two objectives: on the one hand, it makes sighted people sensitive to and understanding of the special needs and challenges of blind people, and provides them with an educational experience that transcends typical stereotypes. On the other hand, blind people are given meaningful employment and training opportunities that will facilitate their return to a working environment in private industry.

The revenue model is based on admission fees (between $€ 9$ and $€ 16$ per visitor) and additional takings from affiliated cafés and special programmes, or from "Dinners in the Dark". As such, the venture is capable of funding itself almost entirely through the revenues it generates itself and is thus largely independent of donations and third-party funds. To date, more than 5 million visitors have been guided through exhibitions, and more than 4,000 blind people have found meaningful jobs through Dialogue in the Dark. This growth results from expanding to several locations. Based on a tested and efficient business model, Dialogue in the Dark has succeeded in extending the social program by means of social franchising.

A systematic expansion through social franchising requires clear-cut organisational structures, which is why Consens Ausstellungs GmbH was set up in 1996. This company is the owner of the standardised concept governing the guided tours through darkened rooms (system package) and simultaneously acts as the franchisor. Dialogue in the Dark makes a distinction between two main forms of franchising: temporary exhibitions, which typically run for six to twelve months and for which the franchisees are predominantly museums, and permanent exhibitions such as those in Holon (Israel) and Campinas (Brazil), for which the franchisees are predominantly social entrepreneurs.

Besides an initial fee for the acquisition of the concept knowledge, the ongoing franchise fees amount to between $€ 130$ and $€ 180$ per day. Since the launch of the idea in 1988 , more than 140 exhibitions in over 20 countries have been staged in this manner, among them more than ten as permanent exhibitions.

\subsection{Science-Lab: Natural sciences for children}

Science-Lab was established in 2002 in Starnberg, Germany as an independent educational initiative for children and primary school teachers. The programme aims "to promote inquirybased thinking to lay a basis for the long-term development of a different understanding of the natural sciences." The founders, Heike Schettler and Sonja Stuchtey, noticed that people generally shied away from the natural sciences and that natural science subjects produced low numbers of graduates. They developed a modern curriculum that provides children aged between four and ten with easy access to various topics in biology, chemistry, physics, 
astronomy and the geosciences. Course formats have been tailored to small children, who are able to get closer to these subjects by means of doing scientific experiments in a playful way.

Science-Lab funds itself both through the offer of supplementary teaching and training for independent infant and primary school teachers, and through course fees amounting to $€ 10$ per course unit and child. Since the launch of the courses, more than 10,000 children have participated in natural science courses, and there further efforts are under way to extend the system throughout Germany. This expansion into new locations takes place through social franchising.

Today, Science-Lab courses are offered in over 70 locations in Germany and abroad. ScienceLab plays the role of the franchisor and course leader. From its headquarters, the company pursues various activities, including the development of the curriculum, the training of new course leaders (franchisees), the continuous training of existing course leaders, as well as all the public relations. The course leaders, in turn, are responsible for all the activities on site.

\subsection{VisionSpring: Glasses to restore eyesight}

VisionSpring was established by Jordan Kassalow and Scott Berrie in New York, in 2001. Originally, it was called the Scojo Foundation. The organisation describes its mission as follows: "To reduce poverty and generate opportunity in the developing world through the sale of affordable eyeglasses."

VisionSpring produces high-quality yet affordable reading glasses for developing countries. The organisation pursues two objectives: on the one hand, it supplies glasses to people in developing countries who otherwise have no access to opticians and/or who do not have the money to afford glasses. On the other hand, VisionSpring provides people with work based on the "Business in a Bag" philosophy, in that individual distributors actually sell those glasses. A majority of these distributors are women, who are thus able to earn a living and have the possibility of pursuing a flexible business besides family and household.

The organisation's revenue model is based on proceeds from glass sales. The final prices of these glasses differ depending on markets and costs but have to satisfy the requirements of cost coverage and affordability for the population. What is important is not only that all the variable costs can be covered, but also that a profit margin is assured at every value creation level. The organisation's overheads are financed by payments from the original company, Scojo Vision LLC, which is a classically profit-oriented enterprise for the production of spectacles and donates $5 \%$ of its pre-tax profits every year.

Since its launch, VisionSpring has managed to sell almost 150,000 pairs of glasses and provide 900 people with a job through the distribution of these glasses. VisionSpring, too, makes use of the social franchising approach to expand its business model. The company expanded to nine countries to date, of which five are served through social franchising.

In its capacity as the franchisor, VisionSpring is responsible for the handover of the concept and the training of the franchisees, as well as for the production of the ophthalmic lenses. In addition, the company constantly supports its franchisees through supplementary training and consultation services, and it takes on part of the marketing activities. The franchise partners organise the entire eyeglass sales operation on site. The franchising fee to be paid to VisionSpring is a function of the number of glasses sold and mainly serves to cover production and transport costs. 


\section{General insights into the concept of social franchising}

The three cases demonstrate a method of multiplying social value creation as opposed to the multiplication of economic value creation pursued by commercial franchises. Cooperation is based on a legal agreement between franchisor and franchisee as is customary with the traditional franchising model. In this agreement, the social enterprise appears as franchisor, while the local multipliers are autonomous units and act as franchisees. As in traditional franchises, cooperation is conceived of as long-term relationship, with the exception of Dialogue in the Dark whom franchisees deliberately agree on temporary cooperation (in the case of temporary exhibitions).

In all three cases, the business model on which the franchise package is based is of a social nature as opposed to the profit orientation of classic franchising. However, like in commercial franchising, all three social franchises give a great deal of significance to a shared brand for the standardisation of market presence. Science-Lab and VisionSpring insist on their franchisees using the brand. In future, Dialogue in the Dark will also enforce the use of a standard brand and corporate identity by all its franchisees.

\subsection{Roles and functions}

The distribution of roles and functions in social franchises largely matches that of commercial franchises. Besides the initial preparation of the concept and the consistent development of the franchise package, the franchisor takes on central activities to support the entire system. Such activities include the administration and control of the franchise system with a special focus on the continuous development (franchise recruitment) and continued existence (quality assurance) of the system, ongoing training, as well as specific on-demand support for franchisees.

To a large extent, the franchisors' responsibility focuses on marketing activities, especially on branding and public relations. Owing to their interest in a standardised market presence, the franchisors support their franchisees through centrally organised public relations efforts and the provision of standardised advertising materials. In contrast to commercial franchises, however, social franchisees directly organise their specific advertising activities themselves. Only advertising measures that are of benefit to the overall system are carried out centrally. Accordingly, the three social franchises do not charge their franchisees for the current marketing and advertising expenses as is typically done by traditional franchises.

The franchisees for their part are responsible for all the activities at their individual locations. This includes the implementation of the social programme on site, which has to be done according to franchise standards. Franchisees are obliged to provide the franchisor with information about the flow of their business activities. Moreover, the payment of a financial franchise fee is contractually agreed in all the social franchises that were investigated. Contrary to the assumptions expressed in the theoretical part, the franchise fees of all three cases observed are thus monetary in nature and thus correspond to the traditional franchises. Besides these running fees, whose amount is either set as a function of turnover (Science-Lab and VisionSpring) or represents a fixed sum subject to the capacity of the franchisee (Dialogue in the Dark), initial payments are also customary. Science-Lab for instance, charges a franchisee and admission fee as compensation for initial expenses such as starter or 
marketing packages, whilst Dialogue in the Dark receives a consultancy fee for consultation services concerning location start-ups.

\subsection{Degree of standardisation}

With regard to standardisation, a distinction can be made between two competing aspects: the necessity of a sufficiently flexible system package for adaptation to local conditions, and the significance of a standardisation of products and processes. Just like commercial franchises, social franchises adapt to local conditions. The three social franchises allow all their franchisees the necessary leeway for the implementation of the concept on site. Carrie Magnuson, Franchise Partner Manager of VisionSpring, says, "It's really important that we are able to offer all the tools, but the organization has to learn how to deploy the services within the context of their particular region."

A high degree of flexibility dominates cooperation with the franchisees in Dialogue in the Dark. Sandra Ortiz, Assistant Manager, points to the efforts made by Dialogue in the Dark to adapt the programme to fit individual franchisees and local circumstances: "First of all, we have to adapt to customers without losing the core... without losing Dialogue in the Dark."

Science-Lab, too, leaves franchisees every possible freedom for entrepreneurial decisionmaking with regard to the implementation of the programme on site, provided franchisees comply with the contractually agreed quality standards. Sonja Stuchtey, a co-founder of Science-Lab, puts it like this: "As long as the franchisees remain within the limits of the quality corridor, our partners are very free."

While social and classic franchises are largely comparable in respect of the necessity to adapt to local conditions, this does not apply to the extent of local freedoms and thus to the extent of the standardisation of products and processes. The above observations alone demonstrate that all three social franchises evidence an extremely high degree of flexibility in that franchisees only have to satisfy minimum standards with regard to the fundamental social concept and qualitative aspects. Thus Andreas Heinecke, the founder of Dialogue in the Dark, only points to three minimum standards that franchisees must categorically adhere to in the preparation and implementation of a local exhibition: "It must be dark, it must be safe, and the blind people are the kings."

\subsection{Structure}

An overview of the basic structure of the three social franchises will serve as the starting point for this section. It is striking that the structures of the three case studies differ greatly from each other, ranging from flat structures with a high number of employees to strongly subdivided configurations with hierarchical structures.

Dialogue in the Dark is characterised by very flat structures, as shown in Figure 1. There is no interim hierarchical level between franchisor and franchisees; all the franchisees report directly to headquarters. 
Figure 1: Franchise structure of Dialogue in the Dark

The franchisee units vary a great deal and range from private individuals who initiate the social programme at their locations to organisations, which, integrate the programme into their existing operations. The latter are predominantly cultural institutions such as museums and cultural centres, which integrate the exhibition concept of Dialogue in the Dark on their own premises. This mixture of various franchisees shows a very heterogeneous group of units. Different thematic origins and diverse infrastructural circumstances result in a situation whereby the franchisor has to respond to each single franchisee in a flexible and individual manner. Whereas existing cultural institutions already have the entire infrastructure, such as box office systems, cloakroom and distribution channels, individual entrepreneurs usually have to set up the entire operation from scratch. The heterogeneity of the franchisees is intensified by the varying geographical locations.

With regard to its hierarchical structure, Science-Lab has a similarly flat structure to Dialogue in the Dark. As depicted in figure 2, the course leaders largely occupy the same level and report directly to headquarters. However, Science-Lab has appointed regional heads who fulfil a supporting function.

Figure 2: Franchise structure of Science-Lab

All the individual network units are private individuals. Cooperation with organisations has been once considered to scale up the business, but his strategy rejected because of quality requirements and the risk of dilution. In spite of the standard network nodes, the individual franchisees differ greatly in terms of their personalities, which are the result of their varying backgrounds. Sonja Stuchtey (Science-Lab) says: "They all have similar motives. [...] but otherwise they're completely different people." 
By contrast, the structure of VisionSpring is somewhat more complex. As depicted in figure 3 VisionSpring uses two franchise channels: a direct one on the right-hand side of the graph, and an indirect one. Whereas the hierarchy is very flat in the direct channel, where there is a direct contact between headquarters and the franchisees, the so-called "Vision Entrepreneurs" is a multilevel organisation. Here, there is first a master franchisee, which in turn serves a number of Vision Entrepreneurs. Generally, there is a master franchisee in each country that is responsible for a up to 25 Vision Entrepreneurs.

Figure 3: Franchise structure of VisionSpring

Generally, it can be concluded that there does not exist a specific structural pattern for social franchises. Rather every social entrepreneur has to decide individually what kind of structure works best as can be seen with the analysed case studies.

\subsection{Intensity of relations}

The aspect of the intensity of relations refers to the micro-level of social capital theory and addresses the nature of relations between the actors according to the distinction between "weak ties" and "strong ties". Overall, the three cases show relations of greatly varying intensity. Bilateral relations between franchisor and franchisees are given and can be called strong in most cases. Whilst many are actively strong in that they are cultivated and are based on regular interaction, others must be conceived of as passively strong since, although there is no regular interaction, the relationship can quickly be activated and intensified if need be. Andreas Heinecke (Dialogue in the Dark) says, "There's everything from zero, little, hardly any interaction to very, very lively, intensive exchange."

Sonja Stuchtey (Science-Lab) confirms this: "There are course leaders from whom you hear relatively little, with relatively little happening there. All those who are committed and do a lot, though, those are in a close exchange, [...] it's really intensive then." Carrie Magnuson (VisionSpring) also refers to the intensive relationship with franchisees: "It's pretty constant communication. [...] When they have problems or run into obstacles or successes we are on the phone and talking through all of those things." 
In contrast to the vertical relations between franchisor and franchisees, the franchisees' horizontal relations tend to be weak to non-existent. In the cases of Dialogue in the Dark and Science-Lab, there are predominantly loose relations between franchisees. These relations find place within annual general meetings (Dialogue in the Dark), further training (Science$\mathrm{Lab}$ ) or on the basis of individual franchisees' geographical proximity (Science-Lab). In the case of VisionSpring, however, any relations between franchisees are purely accidental.

The reason for the relatively weak ties among franchisees in all three social franchises is likely to be the wide geographical distribution of the actors (Dialogue in the Dark, VisionSpring) and the high degree of individuality and entrepreneurial freedom at the various locations.

Given these insights, one can conclude that the network metaphor derived from the social capital theory cannot be applied for social franchising. While social networks are considered as "structure which depicts persons as points and relations as connecting lines" (Granovetter, 1976) and imply flat, dense relational patterns, the analysed cases point to hierarchical and lose structures contrary to network theory.

\section{Management and coordination in social franchises}

\subsection{The selection of franchisees}

The internal coordination of a social franchise starts with the selection of franchisees. It is particularly important to ensure that partners' selection guarantees that the franchise's overall objective can be successfully pursued at the various locations. Therefore, it is necessary to be aware of the qualifications that potential franchisees' require and to be able to vet these candidates accordingly.

In all three cases, the assurance of a moral consensus was given the greatest importance in the selection of franchisees. This consensus can be described based on two factors. First, a potential franchisee must truly embrace the social cause pursued by the franchise and be enthusiastic about it. Second, franchisees generally have a similar conception of how the objectives should be attained and they can therefore actively contribute towards the development of the initiative. VisionSpring, for example, links this criterion to a similar mission and similar objectives to be pursued by a partner organisation, as Carrie Magnuson remarks: "We seek out organizations that have similar missions and goals to implement our program."

Enthusiasm is the driving force that prompts a potential franchisee to support the initiative. This is of immanent significance as a prerequisite since a shared idealism for the social theme is often not complemented fully by classic incentive systems. Silvia Haubs, a franchisee of Science-Lab, says, "I wrote my application on the same day because I was convinced that this was simply a fantastic concept." Andreas Heinecke (Dialogue in the Dark) remarks for his part: "This means that all our franchise partners approached us, they somehow got to know [...] that there was something there that was said to be terrific."

The franchisee's entrepreneurial spirit constitutes a further qualification criterion. This includes a high degree of self-reliance, as well as a mastery of key organisational and management skills. In the case of VisionSpring, a particular attention is given to franchisees' 
business acumen to reach a social objective, whereas Science-Lab and Dialogue in the Dark investigate potential franchisees' entrepreneurial suitability. Anke Burfeind-Herrmann (Dialogue in the Dark) says: "This is why selection is very important. We have to choose the right franchisees... They must also be good on the business side of things, because idealism alone doesn't help."

The selection process of franchisees is important because it stresses both signalling and screening of candidates. The principal/agent theory makes a distinction in the context of establishing contact between signalling, i.e. the provision of information to the better informed party, and screening, the collection of information by the less well informed party.

The case studies show that signalling can take place in different ways either by the franchisor, the franchisee, or third parties. The franchisor provides franchisee candidates with information, particularly to ensure a moral consensus. Since franchisors create an atmosphere of transparency about the low compensation for franchisee activity right from the start, candidates' genuine motivation and expectations are subjected to a test. Sonja Stuchtey (Science-Lab) says in respect of ensuring a moral consensus: "It's relatively easy to make sure it's there. It's because you don't get rich with this business. That means that someone who does it for purely economic reasons may not even get as far as the personal meeting with us." Andreas Heinecke (Dialogue in the Dark), too, says in this context that he is "the worst salesman", since he deliberately reveals unpleasant facts even in the very first cooperation meetings.

With regard to screening, a distinction can be made between two courses of action: a rigid examination, which is driven by facts, and an intuitive examination, which is driven by emotion. A rigid, fact-driven examination is characterised by a thorough analysis of the candidate to throw light on his or her qualifications. Practices range from the classic application procedure, including an examination of the curriculum vitæ and a personal meeting (Science-Lab), a thorough due diligence examination of the applicant organisation (VisionSpring) to the completion of a qualifying period (Science-Lab, VisionSpring).

Conversely, the intuitive, emotion-driven examination, which Dialogue in the Dark used in the past, encompass elements were the assessment of mainly soft factors such as credibility, cooperation skills, and the interpersonal "fit" among the actors. This happened through long personal meetings aiming to establish a relationship between the potential partners. As Andreas Heinecke (Dialogue in the Dark) recounts: "The understanding of what kind of person you actually are; what we actually have some common ground, and whether we are able to do something together is paramount for the selection process of franchisees. [...] There is no examinations as such, but you find out in discussions where you come from, what you do, what you have, and what you are."

\subsection{Contractual coordination}

As a rule, contractual coordination constitutes the main instrument for the control of commercial franchises and is emphasised by the principal/agent theory. Generally, a legal agreement, which governs determinants of cooperation (e.g. remuneration, premium payments and control systems) is the main coordination mechanism.

In all three case studies, there is a legal agreement, which stipulates the parameters of the franchise relationship. It sets out the franchisors and franchisees' rights and obligations, including the monies to be paid, the type and extent of control systems, the communication 
requirements, as well as territorial coverage. Despite this clear weighting of contractual agreements, it is a common feature of all three social franchises that the legal agreement has only a minor significance as a steering instrument in the actual cooperation between the parties. This is however the case in many commercial franchises.

The contract is regarded as a necessary legal basis for the partnership, but perhaps most importantly, the coordination is constituted by the social relationships between the people involved. Carrie Magnuson (VisionSpring) explains: "We obviously have the contract to back us up, and that's really important to have that like in any business. But at the same time it's better if we don't necessarily have to call on that contract, to enforce it."

When asked whether the contract is really used to deal with irregularities in the franchise relationship franchisees like Anke Burfeind-Herrmann (Dialogue the Dark) says, "No, it says right at the start in the preamble that you try to get your rights by mutual consent and do business together. This agreement is only meant to lay down some benchmark standards. We actually try to sort out problems through a dialogue between the parties involved."

The analysis of the three social franchises reveals that franchisees always receive financial compensation for their activities and that this compensation represents the residual amount of turnover less franchise fee. Consequently, the principle of franchising, whereby franchisees act as entrepreneurs and thus bear part of the risk, holds true. In all three cases, the franchisees' business success determines the size of the actual remuneration, thus constituting a classic motivation instrument in accordance with the principal/agent theory. In the cases of Science-Lab and VisionSpring, the beneficiaries themselves pay for the social assistance (the children's parents pay for the course units provided by Science-Lab, while people with deficient eyesight pay for the glasses provided by VisionSpring). In the case of Dialogue in the Dark, franchisees are remunerated by the exhibitions' visitors. The importance of a service that results in financial compensation is emphasised by all three social franchises alike. " $A$ very important aspect, we don't cooperate with people who do voluntary work. We all feel responsible for what we do because we're paid for it. How much doesn't matter at all," says Sonja Stuchtey, co-founder of Science-Lab.

Control plays an important part in the overall coordination of commercial franchise systems and is an important factor in franchisor/franchisee relations. The principal/agent theory postulates that hidden activities and information result in moral hazard such as quality uncertainties and hold-up hazards such as the appropriation of the business concept by a franchisee.

The importance of control in cooperation with franchisees is shared by all the social franchises that were analysed. However, control systems varied greatly in the three organisations analysed. Indeed, very rigid, structured and rather less structured control procedures could be observed. The most comprehensive measures are taken by Science-Lab. The franchise contract requires that franchisees submit written feedback forms on every course unit and distribute questionnaires to the children's parents in the courses. These questionnaires must be submitted for central evaluation. Moreover, franchisees have to participate in annual training courses to extend their competencies.

VisionSpring control mechanisms are organised in a similarly formal way. This organisation uses an Internet database into which franchisees regularly log their key turnover figures. This benchmark reporting has a two-tier structure in that so-called District Managers agree a loose form of turnover objectives with headquarters and coordinate their $20-25$ Vision 
Entrepreneurs accordingly. In addition, VisionSpring provides training courses for Vision Entrepreneurs to improve service quality.

By contrast, Dialogue in the Dark only recently included control mechanisms in its agreements. Previously, reporting by franchisees was predominantly based on "personal relations" and took place on a voluntarily basis. The control mechanisms implemented by Dialogue in the Dark are less formal than in the two other cases. Regular personal contact and on-site inspections play a central role in Dialogue in the Dark's quality assurance. This can also be recognised from their consulting activities for each newly admitted franchisee, which are personnel intensive and are mostly conducted on site.

\subsection{Social coordination}

As we outlined in the review of the literature, coordination in franchises takes place not only through legal contracts and control procedures but also through different social mechanisms. Among those, trust is often mentioned as the bedrock of commercial franchises. Our analysis shows that this is also an important factor for social franchises.

Trust is not only an admission criterion for the selection of new franchisees and thus a constituent feature, but it is further strengthened by cooperation during the social franchise launch and development. Since social franchises are systems that consist of people, a strong interweaving of different forms of trust can be discerned: trust in the organisation and in people, with the latter form being subdivided into horizontal trust between franchisees and vertical trust between franchisor and franchisee. Although the cause-and-effect relationship between trust and social relations remain often unclear three elements of trust are worth mentioning.

First, in all three cases trust has a particularly fertile soil in the collective, charitable objective of the social franchise in question. The shared mission and goals provide a thrust for cooperation and make transparent what the social franchise system as a whole stands for. In her answer to the question concerning the problems and conflicts in the cooperation among franchisor and franchisees, Silvia Haubs (Science-Lab) refers to the fact that cooperation has been free of trouble to date owing to the high density of connecting elements: "The absence of problems is due to the fact that we all pull together, that is, we're all equally enthusiastic and one profits from the other."

The interviews make clear that organisational trust is of great significance. This trust is generated by professional competence on the part of the franchisor. The knowledge of the social franchise acquired at headquarters generates trust among franchisees if this knowledge is made available when the need arises. Then again, this access requires a further ingredient, namely an open, trusting climate within the franchise system. In addition this manifests itself in fair interpersonal relations, open communication channels, and the greatest possible readiness to cooperate with each other. Bettina Deutsch-Dabernig (Dialogue in the Dark) refers to the trusting, open climate in the organisation and points out to: "The people at headquarters, who really give the impression that they care about things. If you have worries during the ongoing operation, you can always go to these people." Silvia Haubs (ScienceLab) also emphasises to the trusting climate: "There's always a perfectly open relationship and everyone also knows that suggestions are always warmly welcomed."

When it comes to establishing organisational trust, the closely associated feeling of personal trust between the franchise partners has a role to play. Contrary to the original assumption of a 
high level of horizontal trust among franchisees, the cases investigated hardly provide any evidence of this. However, a strong vertical trust between headquarters and franchisees emerged as a pattern in all three cases. Trust is built on the support provided by the franchisor to his franchisees. Continuous communication and a constant readiness to provide help are typical characteristics of this relationship. "When we get the impression that there's a quality problem, we get into contact at once. That is, we immediately offer support for qualification," says Sonja Stuchtey (Science-Lab).

Andreas Heinecke (Dialogue in the Dark) goes even further and conceives trust in franchisees not only as the basis for cooperation but as a substitute for contractual arrangements: "When all is said and done, the lack of legal exactitude and the possibility of financial pressure can only be balanced out if you have an open personal relationship. This is where you have to invest, you have to be open, to be able to approach people, to be able to let yourself in for a surprise, and this is precisely where you shouldn't act according to revenues and expenses.'

Whereas the level of trust in social franchises is very high, in all three case studies control is exercised solely from the centre or in isolated cases by individuals within the system but not by the entire group as a collective as proposed by social capital theory. In the light of the above-mentioned gaps inherent in the franchise structures, this appears logical. Networkspecific social standards require closed network structures, which do not exist in social franchising. The interviewees were unable to name any structure or relation patterns that underpin network dynamics and no special extent of social standards can be made out at first. However, deeper analyses reveal that social standards do exist and furthermore play a critical role throughout all three social franchises.

First, social franchises represent subsystems of the society and naturally are subject to the same rules of behaviour as the wider societal system. Therefore, reciprocity standards typical of social systems are also in place. "Give and take" symbolises that distinctly cooperative behaviour in social franchises and shows the great importance of reciprocity in social relations. Second, the franchisors themselves induce social standards due to their strong and powerful position within the systems as the example of Heinecke referring to quality as a "huge topic" throughout Dialogue in the Dark, where the franchise centre acts "very rigidly" shows. By stressing the importance to adhere to nonnegotiable quality levels franchisors automatically set social standards acting as social coordination mechanism in the respective social franchise system.

\begin{tabular}{|c|c|c|}
\hline & Dialogue in the Dark & VisionSpring \\
\hline \multicolumn{3}{|c|}{ Selection of franchisees } \\
\hline Requirement & \multicolumn{2}{|c|}{ Moral consensus, entrepreneurial spirit } \\
\hline \multirow[t]{2}{*}{$\begin{array}{l}\text { Selection } \\
\text { process }\end{array}$} & \multicolumn{2}{|c|}{$\begin{array}{l}\text { Thorough examination (curriculum vitae, due diligence, personal meeting, qualifying } \\
\text { period) }\end{array}$} \\
\hline & $\begin{array}{l}\text { (in past: intuitive } \\
\text { examination) }\end{array}$ & \\
\hline
\end{tabular}




\begin{tabular}{|c|c|c|}
\hline Legal contract & \multicolumn{2}{|c|}{ Rights and obligations of franchise parties } \\
\hline Compensation & \multicolumn{2}{|c|}{$\begin{array}{l}\text { Residual of revenue and franchise fee, high importance of non-material forms of } \\
\text { compensation }\end{array}$} \\
\hline \multirow{2}{*}{$\begin{array}{l}\text { Control } \\
\text { systems }\end{array}$} & \multicolumn{2}{|c|}{ High importance of contractual controls } \\
\hline & $\begin{array}{l}\text { (in past: low importance } \\
\text { of contractual controls) }\end{array}$ & \\
\hline \multicolumn{3}{|c|}{ Social coordination } \\
\hline Trust & \multicolumn{2}{|c|}{$\begin{array}{l}\text { Organisational and vertical (franchisor and franchisees) trust of high importance, } \\
\text { horizontal trust of low importance, complementary coordination function }\end{array}$} \\
\hline \multirow[t]{2}{*}{$\begin{array}{l}\text { Social } \\
\text { standards }\end{array}$} & \multicolumn{2}{|c|}{$\begin{array}{l}\text { Substitute for lack of process-related standards, corroboration of contractual } \\
\text { agreement with regard to quality and behavioural aspects }\end{array}$} \\
\hline & \multicolumn{2}{|r|}{ Reciprocity standard } \\
\hline \multirow[t]{2}{*}{ Identity } & \multicolumn{2}{|c|}{ Varying, complementary coordination function } \\
\hline & & High importance of consistent brand for internal identity \\
\hline
\end{tabular}

Table 1: Overview of the coordination mechanisms in the three cases

\section{Conclusion}

The chapter provided an insight in the nature of social franchises as business model to scale up social ventures. Our analysis focused on the structure and coordination of social franchises. The results confirm the original assumption that social franchising does indeed represent a form of franchising as it is known from the commercial sector. Typical franchise elements such as an agreement on longer-term cooperation between franchisor and franchisee based on a legal contract, the payment of a franchise fee, as well as the interplay between control and entrepreneurial freedom in the actors' relationships are applied in social franchising, too. However, the transposition into social entrepreneurship results in differences from the commercial form.

The most important difference from traditional franchises concerns the ultimate goal of social franchising. Although both the traditional model and social franchising aim to distribute a business concept, the latter does not accord primary importance to a uniform market presence intended to generate a high degree of brand recognition and to build up a customer base who will buy the product again and again. In contrast to the economic objective of generating the highest possible financial profit, social franchises strive to achieve the highest possible social profit. The goal of social franchises is a far-reaching and optimal satisfaction of social needs 
as opposed to the high degree of brand recognition and customer loyalty pursued by traditional franchises.

A second differentiating feature can be recognised in the different incentive structures offered by social and commercial franchises. The pervasive lack of funds in the social sector prevents its actors from being paid adequate financial compensation, which is why the franchisees' motivation and commitment is largely non-material. Thus the incentive for social franchisees may reside in the fun and pleasure derived from the activities, the recognition received for their work, the creative leeway provided by entrepreneurial activities on site, or the high degree of meaningfulness generated by the social value creation.

The third difference between social and commercial franchises is to be found in the importance of quality. In analogy with the difference in objectives, the quality of service/product provision to customers serves to fulfil different purposes. Whereas, for commercial franchises the importance of quality lies in maintaining customer loyalty through the provision of satisfactory or exciting products/services, the quality offered by social franchises is not primarily intended to create customer ties. Rather, its object is the best possible satisfaction of customers, which means that quality plays a part in the assurance of qualitative minimum standards and the prevention of loss in the generation of social goods.

With regard to the chosen theoretical frame of reference, results suggest that the principal/agent theory offers a valuable approach for social franchising. Although the validity of the approach was assumed to be given, albeit limited, in the theoretical part, the economic orientation of the approach allows for an excellent depiction of the professional, business side of social franchising that was so often emphasised by the interviewees. Basic agencytheoretical findings could be positioned in relation to social franchising, and concrete findings were generated: besides the validity of the principal/agent relationship between franchisor and franchisees and their typical risks, the theory provides suggestions for control mechanisms to reduce uncertainty that are either relevant (legal agreement, remuneration, control systems, standards) or less relevant (trust, identity). Once again, the "business" character of social franchising and social entrepreneurship can thus be emphasised.

Concepts of social capital theory also provided interesting findings. The clarification of the meaning of trust, standards and identity with relation to internal coordination gives evidence of the mode of operation and the interaction of cooperation between franchise partners. However, the findings also show that this has only been an initial step and that further research is required. Thus a more detailed investigation of the social capital features, such as the multi-layered construct of trust, against the background of the special way of thinking and the attitudes of the actors involved, would be interesting. Moreover, the findings reveal the relevance of other constructs such as power and influence and the significance of social obligations in social franchise systems, whose examination would have been beyond the scope of this paper.

\section{References}

Adler, P. S., \& Kwon, S.-W. 2002. Social Capital: Prospects for a New Concept. Academy of Management Review, 27(1): 17-40. 
Ahlert, D., Fleisch, H., Dinh, H. V. D., Heußler, T., Kilee, L., \& Meuter, J. 2008. Social Franchising - A Way of Systematic Replication to Increase Social Impact. Berlin: Bundesverband Deutscher Stiftungen.

Ashforth, B. E., \& Mael, F. 1989. Social Identity Theory and the Organization. The Academy of Management Review, 14(1): 20-39.

Austin, J. et al. (2006): Social and Commercial Entrepreneurship: Same, Different, or Both?, Entrepreneurship Theory \& Practice, 30: 1-22.

Blomqvist, K. 1997. The Many Faces of Trust. Scandinavian Journal of Management, 13(3): 229-329.

Bradach, J.L. 1997, 'Using the Plural Form in the Management of Restaurant Chains,' Administrative Science Quarterly, 42 (2): 276-303

Burt, R. S. 1992. Structural Holes -The Social Structure of Competition. Cambridge: Harvard University Press.

Carney, M. \& Gedajlovic, E. 1991, 'Vertical Integration in Franchise Systems: Agency Theory and Resource Explanations', Strategic Management Journal, (12): 607-29

Coleman, J. 1990. Foundations of Social Theory. Cambridge.

Combs, J. G., Michael, S. C., \& Castrogiovanni, G. J. 2004. Franchising: A Review and Avenues to Greater Theoretical Diversity. Journal of Management, 30(6): 907-931.

Dees, J. G. 1998. The meaning of "Social Entrepreneurship". Unpublished First draft, Stanford University, Stanford.

Eisenhardt, K. M. 1989, 'Agency theory: an assessment and review', Academy of Management Journal, 14 (1): 57-74.

Franz, S. 2004. Grundlagen des ökonomischen Ansatzes: Das Erklärungskonzept des Homo Oeconomicus. Unpublished Working paper, Universität Potsdam, Potsdam.

Garg, V. K. \& Rasheed, A. A. 2003, 'International multi-unit franchising: an agency theoretic explanation', International Business Review, (12) 329-48

Granovetter, M. S. 1973. The Strength of Weak Ties. The American Journal of Sociology, 78(6): 1360-1380.

Granovetter, M. S. 1976. Network Sampling: Some First Steps. The American Journal of Sociology, 81, 1287/1303.

Granovetter, M. S. 1983. The Strength of Weak Ties: A Network Theory Revisited. Sociological Theory, 1: 201-233.

Kleine, A. 1995. Entscheidungstheoretische Aspekte der Principal-Agent-Theorie. Heidelberg: Physica Verlag.

Lin, N. 2001. Social Capital - A Theory of Social Structure and Action. Cambridge: Cambridge University Press.

Macaulay, S. 1963. Non-Contractual Relations in Business: A Preliminary Study. American Sociological Review, 28(1): 55-67.

Morgan, R. M. \& Hunt, S. D. 1994, 'The commitment-trust theory of relationship marketing', Journal of Marketing, vol. 20 (July): 20-38

Nahapiet, J., \& Ghoshal, S. 1998. Social Capital, Intellectual Capital, and the Organizational Advantage. Academy of Management Review, 23(2): 242-266.

Ripperger, T. 1998. Ökonomik des Vertrauens - Analyse eines Organisationsprinzips. Tübingen: Mohr Siebeck Verlag.

Robson, C. 1993, Real World Research: A Resource for Social Scientists and Practitioner-Researchers, Blackwell, London

Ross, S. A. 1973. The Economic Theory of Agency: The Principal's Problem. American Economic Review, 63: 134-139.

Shane, S.A. 1996, 'Hybrid organisational arrangements and their implications for firm growth and survival: A Study of New Franchisors,' Academy of Management Journal, 39(1): 216-34 
Schechler, J. M. 2002. Sozialkapital und Netzwerkökonomik. Frankfurt am Main: Peter Lang Verlag.

Skaupy, W. 1995. Franchising: Handbuch für die Betriebs- und Rechtspraxis. München: Franz Vahlen Verlag.

Spremann, K. 1987. Agent and Principal. In G. Bamberg, \& K. Spremann (Eds.), Agency Theory, Information, and Incentives: 3-42. Heidelberg: Springer Verlag.

Sydow, J. 1998. Franchise Systems as Strategic Networks: Studying Network Leadership in the Service Sector. Asia Pacific Journal of Marketing and Logistics, 10: 108-120.

Tracey, P., \& Jarvis, O. 2007. Toward a Theory of Social Venture Franchising. Entrepreneurship Theory \& Practice, 31(5): 667-685.

Yin, R. K. 2003, Case Study Research: Design and Methods, $3^{\text {rd }}$ ed., Sage Publications, Thousand Oaks.CA.

Zahra, S. A., Rawhouser, H. N., Bhawe, N., Neubaum, D. O., \& Hayton, J. C. 2008. Globalization of Social Entrepreneurship Opportunities. Strategic Entrepreneurship Journal, 2: 117-131. 